\title{
IMPLEMENTASI PERMENPAREKRAF NO. 4 TAHUN 2014 TENTANG STANDAR USAHA BIRO PERJALANAN WISATA PADA PELAKU USAHA BIRO PEJALANAN WISATA HAJI DAN UMROH DI YOGYAKARTA
}

\author{
Elisa Dwi Rohani ${ }^{1}$, Cerry Surya Pradana ${ }^{2}$ \\ Email: elisa.dwi.rohani@ugm.ac.id ${ }^{1}$, cerrysuper@ugm.ac.id ${ }^{2}$ \\ 1,2Program Studi Bisnis Perjalanan Wisata, Fakultas Sekolah Vokasi, \\ Universitas Gadjah Mada, Yogyakarta
}

\begin{abstract}
There are not a few travel agencies that move in the field of Hajj and Umrah that do not have business legality, therefore there needs to be supervision and application of business standards for businesses BPW Hajj and Umrah. The business standard of this travel agency not only applies to BPW who are active in inbound and outbound tour packages but this regulation also applies to BPW which focuses on Hajj and Umrah spiritual travel. Even every BPW Hajj and Umrah is required to have a business certificate of travel agency services in order to obtain a permit for The Umrah Ibadah Travel (PPIU). This research will be carried out on BPW Hajj and Umrah who have certified BPW business field in Yogyakarta which aims to see the extent to which standardization of this business can be applied to businesses and what obstacles faced in the application of business standards. This research uses qualitative research method to obtain data and information needed data collection techniques used in this research including Indepth Interview, observation and policy studies. The results of this study showed that the fundamental problems that are addressed by BPW Hajj and Umrah businesses do not have a valid business license, current and adequate, do not have cooperation with outside parties, especially with vendors, often found BPW business which is a cooperation between friends and family members, as well as the lack of socialization of BPW standards to BPW Hajj and Umrah businesses that are more focused on Umrah activities.
\end{abstract}

Abstrak: Saat ini tidak sedikit dijumpai biro perjalanan wisata yang begerak dalam bidang Haji dan Umroh yang tidak memiliki legalitas usaha, maka dari itu perlu adanya pengawasan dan penerapan standar usaha bagi pelaku usaha BPW Haji dan Umroh. Menariknya standar usaha Biro perjalanan ini tidak hanya berlaku bagi BPW yang aktif dalam paket wisata inbound dan outbound tetapi peraturan ini juga berlaku pada BPW yang fokus pada perjalanan rohani Haji dan Umroh. Bahkan setiap BPW Haji dan Umroh diwajibkan memiliki sertifikat usaha jasa biro perjalanan guna mendapatkan ijin Penyelenggaran Perjalanan Ibadah Umroh (PPIU). Penelitian ini akan dilaksanakan pada BPW Haji dan Umroh yang telah melakukan sertifikasi Bidang Usaha BPW yang berada di Yogyakarta yang bertujuan untuk melihat sejauh mana standarisasi usaha ini mampu di terapkan bagi pelaku usaha serta kendala apa yang dihadapi dalam penerapan standar usaha. Penelitian ini mengunakan metode penelitian kualitatif untuk mendapatkan data dan informasi yang dibutuhkan teknik pengumpulan data yang digunakan dalam penelitian ini diantaranya adalah Wawancara Mendalam (Indepth Interview), observasi dan studi kebijakan. Hasil dari penelitian ini terlihat bahwa permasalahan mendasar yang di hadapi oleh pelaku usaha BPW haji dan Umroh belum memiliki ijin usaha valid, terkini dan memadai, tidak memilik kerjasama dengan pihak luar khususnya dengan vendor, sering dijumpai usaha BPW yang merupakan kerjasama antar teman dan anggota keluarga, serta kurangnya sosialisasi standar BPW kepada pelaku usaha BPW haji dan Umroh yang lebih fokus kepada aktivitas ibadah Umroh.

Keywords: business standards, travel agency, hajj and umrah, yogyakarta. 


\section{PENDAHULUAN}

Pariwisata merupakan salah satu sektor andalan Indonesia untuk meningkatkan pemasukan bagi negara. Bahkan Presiden Joko Widodo telah menjadikan pariwisata sebagai sektor prioritas bersama maritim, pangan, energi dan infrastruktur. Dalam pengembangannya kepariwisataan diarahkan pada pertumbuhan dan pemerataan ekonomi untuk kesejahteraan rakyat. Pembangunan kepariwisataan Indonesia berorientasi pada pengembangan wilayah, bertumpu kepada masyarakat, dan bersifat memberdayakan masyarakat yang mencakup berbagai aspek. Aspek-aspek tersebut meliputi sumber daya manusia, pemasaran, destinasi, ilmu pengetahuan dan teknologi, keterkaitan lintas sektor, kerja sama antarnegara, pemberdayaan usaha kecil, serta tanggung jawab dalam pemanfaatan sumber kekayaan alam.

The Travel \& Tourism Competitiveness Report 2019 yang disusun oleh World Economic Forum menyebutkan setidaknya ada 14 penilaian yang meliputi 1) Lingkungan hidup yang terdiri dari Lingkungan bisnis, Keselamatan dan keamanan, Kesehatan dan Kebersihan, Sumber Daya Manusia dan, Pasar Tenaga Kerja serta Kesiapan Teknologi, 2) kebijakan dan kondisi perjalanan dan pariwisata yang terdiri dari Prioritas dari Perjalanan \& Pariwisata, Keterbukaan Internasional, Daya Saing Harga dan Keberlanjutan, 3) Infrastruktur yang terdiri dari Infrastruktur Transportasi Udara, Ground dan Port Infrastruktur, serta Layanan Turis, 4) Sumber Daya Alami dan Budaya yang terdiri dari Sumber daya alam dan Sumber Daya Budaya dan Perjalanan Bisnis.

Salah satu pendorong meningkatnya indeks daya saing pariwisata adalah Biro Pejalanan Wisata yang menyediakan jasa untuk memenuhi kebutuhan wisatawan. Peraturan Menteri Kebudayaan dan Pariwisata Republik Indonesia Nomor PM.85/HK.501/MKP/2010 yang mengatur Cara Pendaftaran Usaha Jasa Perjalanan Wisata disebutkan dalam, pasal 1 bab 1 pada yang dimaksud dengan Biro perjalanan wisata adalah usaha penyediaan jasa perencanaan perjalanan dan/atau jasa pelayanan dan penyelenggaraan pariwisata, termasuk penyelenggaraan perjalanan ibadah. Biro Perjalanan Wisata memilik peran dalam 1) menyusun dan merencanaan komponen perjalanan wisata, terdiri dari sarana dan prasarana wisata, daya tarik wisata yang yang akan dikunjungi, 2) jasa penjualan paket wisata baik dijual secara mandiri maupun bekerjasama dengan agen perjalanan wisata dan maupun menjualnya langsung kepada wisatawan, 3) jasa pramuwisata, 4) pemesanan transportasi wisata, 5) pemesanan restoran, akomodasi, tiket pertunjukkan seni budaya, dan kunjungan ke objek wisata, 6) jasa layanan dokumen perjalanan, 7) penyelengaraan perjalanan ibadah agama, dan 8) penyelenggaraan perjalanan insentif (Kesrul, 2003:11)

Sebuah Biro Perjalanan Wisata atau BPW dapat menciptakan, mengembangkan dan menjual produk mereka sendiri ke pelanggan selain hanya sebagai perantara dengan menjual jasa dan produk pariwisata hal ini menjadi salah satu peran BPW sebagai Organizer. Biro Perjalanan Wisata merupakan salah satu produk dari industri pariwisata dalam bidang usaha perjalanan wisata. Biro Perjalanan Wisata yang disingkat dengan BPW, memilik peran cukup penting untuk dapat meningkatkan pendapatan pemerintah melalui paket-paket wisata baik paket wisata inbound, paket wisata outbound maupun paket wisata khusus Haji dan Umroh. Berdasarkan pada Peraturan Menteri Pariwisata Ekonomi Dan Kretaif No.4 Tahun 2014 Yang Memuat Tentang Standar Usaha Biro Perjalanan Wisata mengatur standar BPW agar dapat memenuhi kriteria baik dalam aspek produk, aspek pelayanan dan pengelolaan.

Menariknya standar usaha Biro Perjalanan Wisata ini tidak hanya berlaku bagi BPW yang aktif dalam paket wisata inbound dan outbound tetapi peraturan ini juga berlaku pada BPW yang fokus pada perjalanan rohani Haji dan Umroh. Bahkan setiap BPW yang bergerak dalam pelayanan ibadah Haji dan Umroh diwajibkan memiliki sertifikat usaha jasa BPW guna mendapatkan ijin Penyelenggaran Perjalanan Ibadan Umroh (PPIU). Sayangnya sampai saat ini tidak banyak BPW Haji dan Umroh yang memiliki sertifikat usaha BPW, bahkan BPW yang telah memiliki setifikat tidak mampu memenuhi standar yang telah ditetapkan. Berdasarkan pada Peraturan Menteri Agama Republik Indonesia Nomor 8 Tahun 2018 Tentang Penyelenggaraan Perjalanan Ibadah Umroh disebutkan pada bab 2 pasal 5 untuk memiliki izin operasional sebagai PPIU diwajibkan 
memiliki sertifikat usaha biro perjalanan wisata yang masih berlaku. Oleh sebab itu setiap BPW yang akan mengajukan maupun perpanjangan ijin oprasional PPIU wajib memilik sertifikasi Biro Perjalanan Wisata yang dikeluarkan oleh Lembaga Sertifiksi Usaha yang bersifat independen.

Penelitian ini akan membahas seberapa pentingnya standarisasi usaha BPW bagi pelaku usaha Haji dan Umroh, mengingat banyaknya usaha BPW Haji dan Umroh yang belum memiliki ijin usaha BPW, serta lemah system pengawasan terhadap pelaku usaha. Selain itu dalam penelitian ini juga melihat dan mengali sejauh mana implementasi Permenparekraf No.4 Tahun 2014 tentang standar usaha biro perjalanan wisata pada pelaku usaha biro pejalanan wisata haji dan Umroh di Yogyakarta. Oleh sebab itu, dalam penelitian ini akan membahas sejauh mana BPW yang bergerak dalam usaha haji dan Umroh mampu menerapkan standar usaha untuk memberikan pelayanan yang terbaik bagi calon jamaah serta menjamin terlaksananya Haji dan Umroh sesuai dengan yang dijanjikan. Pertanyaan penelitian yang akan dibahas pertama, mengapa BPW perlu menerapakan standar usaha BPW, kedua, apa yang menjadi kendala bagi BPW Haji dan Umroh untuk mengimpmentasikan standar BPW.

Daerah Istimewa Yogyakarta memilik cukup banyak Biro Perjalanan Wisata yang melayani kebutuhan wisatawan wisatawan domestik dan wisatawan mancanegara. Berdasarkan pada data Badan Pusat Statistik Provinsi Daerah Istimewa Yogyakarta tahun 2019, jumlah Biro Perjalanan di Yogyakarta terus mengalami peningkatan sebanyak 742 BPW, 19 Cabang BPW dan 102 APW. Berikut data BPW, CBPW, dan APW Yogyakarta 5 tahun terakhir.

Tabel 1. Jumlah Biro Perjalanan Wisata di Yogyakarta

\begin{tabular}{lccccc}
\hline \multirow{1}{*}{ Usaha } & \multicolumn{5}{c}{ Tahun } \\
\cline { 2 - 6 } & $\mathbf{2 0 1 4}$ & $\mathbf{2 0 1 5}$ & $\mathbf{2 0 1 6}$ & $\mathbf{2 0 1 7}$ & $\mathbf{2 0 1 8}$ \\
\hline $\begin{array}{l}\text { Biro } \\
\text { perjalanan } \\
\text { wisata } \\
\text { (BPW) }\end{array}$ & 473 & 602 & 589 & 570 & 742 \\
\hline $\begin{array}{l}\text { Cabang biro } \\
\text { perjalanan } \\
\text { wisata }\end{array}$ & 19 & 19 & 176 & 19 & 19 \\
\hline
\end{tabular}

\begin{tabular}{lccccc}
\hline (CBPW) & & & & & \\
\hline $\begin{array}{l}\text { Agen } \\
\text { perjalanan } \\
\text { wisata } \\
\text { (APW) }\end{array}$ & 21 & 55 & 74 & 106 & 102 \\
\hline Jumlah & 513 & 676 & 839 & 695 & 863 \\
\hline
\end{tabular}

Sumber: Badan Pusat Statistik DIY, 2019.

Dari tabel 1 terlihat bahwa jumlah Biro Perjalanan Wisata paling banyak jika dibandingankan dengan Cabang BPW dan agen perjalanan wisata, bahkah ditahun 2018 tercatat sebanyak 742 BPW yang beroprasi di Yogyakarta. Di Indonesia biro perjalanan wisata yang telah memilik ijin PPIU dari kementerian Agama saat ini mencapai 991 BPW yang terdiri dari kantor cabang dan pusat. Sedangkan Yogyakarta saat ini memilik 18 pusat dan 50 cabang PPIU yang telah tersertifikasi sebagai Biro Perjalanan Wisata. Semakin ketatnya peraturan yang disusun oleh pemerintah bagi pelaku usaha BPW Haji dan Umroh hal ini mengakibatkan semakin banyak BPW yang berusaha memenuhi peraturan dan ketentuan pemerintah guna mendapatkan ijin usaha Penyelenggaraan Ibadah Haji dan Umroh.

Bagi umat muslim melaksanakan ibadah haji dan Umroh merupakan sunah sehingga tidak sedikit umat muslim di Indonesia yang mampu melaksanakan ibadah haji dan Umroh. Jumlah jamaah hai Indonesia terus mengalami peningkatan sejak tahun 2016, bahan di tahun 2018, jumlah Jemaah haji Indonesia mengalami peningkatan $0,13 \%$ mencapai 203.070 jamaah. Jumlah jamaah Haji tertinggi terjadi pada tahun 2017 sebanyak 31,5\% seiring dengan penambahan kuota menjadi 221.000 jamaah. Kebijakan Pemerintah Arab Saudi menunda kedatangan jamaah Umroh ke Tanah Suci, Mekkah, termasuk Indonesia oleh otoritas Arab Saudi hal ini berdampak secara langung terhadap pelaksanaan ibadah haji pada tahun 2020. (BPS, 2018) Berikut tabel PPIU pusat yang ada di Yogyakarta. 
Tabel 2. Penyelenggaran Ibadah Haji dan Umroh di Yogyakarta

\begin{tabular}{|c|c|c|}
\hline No. & Nama & No. SK \\
\hline 1. & $\begin{array}{l}\text { PT. Mutiara Kabah } \\
\text { Wisata }\end{array}$ & $\begin{array}{l}\text { Nomor } 555 \text { Tahun } \\
2018\end{array}$ \\
\hline 2. & $\begin{array}{l}\text { PT. Freshnel } \\
\text { Kreasindo Perkasa }\end{array}$ & $\begin{array}{l}\text { Nomor } 276 \text { Tahun } \\
2018\end{array}$ \\
\hline 3. & $\begin{array}{l}\text { PT. Alfajr Baladi } \\
\text { Indonesia }\end{array}$ & Nomor 53 Tahun 2018 \\
\hline 4. & $\begin{array}{l}\text { PT. Surya Citra } \\
\text { Madani }\end{array}$ & $\begin{array}{l}\text { Nomor } 927 \text { Tahun } \\
2017\end{array}$ \\
\hline 5. & $\begin{array}{l}\text { PT. Laraiba } \\
\text { Madania Wisata }\end{array}$ & $\begin{array}{l}\text { Nomor } 900 \text { Tahun } \\
2017\end{array}$ \\
\hline 6. & $\begin{array}{l}\text { PT. Nabawi Mulia } \\
\text { Utama }\end{array}$ & $\begin{array}{l}\text { Nomor } 902 \text { Tahun } \\
2017\end{array}$ \\
\hline 7. & $\begin{array}{l}\text { PT. Rozi Global } \\
\text { Madani }\end{array}$ & $\begin{array}{l}\text { Nomor } 693 \text { Tahun } \\
2017\end{array}$ \\
\hline 8. & $\begin{array}{l}\text { PT. Cahaya Imani } \\
\text { Haji Umroh }\end{array}$ & $\begin{array}{l}\text { Nomor } 933 \text { Tahun } \\
2019\end{array}$ \\
\hline 9. & $\begin{array}{l}\text { PT. Zhafirah Mitra } \\
\text { Madina }\end{array}$ & $\begin{array}{l}\text { Nomor } 117 \text { Tahun } \\
2019\end{array}$ \\
\hline 10. & PT. At Tiqnu & $\begin{array}{l}\text { Nomor } 118 \text { Tahun } \\
2019\end{array}$ \\
\hline 11. & PT. Permata Umat & $\begin{array}{l}\text { Nomor } 116 \text { Tahun } \\
2019\end{array}$ \\
\hline 12. & $\begin{array}{l}\text { PT. Total Nusa } \\
\text { Indonesia }\end{array}$ & $\begin{array}{l}\text { Nomor } 697 \text { Tahun } \\
2017\end{array}$ \\
\hline 13. & $\begin{array}{l}\text { PT. Nuansa Ceria } \\
\text { Pesona }\end{array}$ & $\begin{array}{l}\text { Nomor } 765 \text { Tahun } \\
2017\end{array}$ \\
\hline 14. & $\begin{array}{l}\text { PT. Baitul Izzah } \\
\text { One Nahdliyah } \\
\text { Tolchah Mansoer }\end{array}$ & $\begin{array}{l}\text { Nomor } 172 \text { Tahun } \\
2019\end{array}$ \\
\hline 15. & $\begin{array}{l}\text { PT. Nur Ramadhan } \\
\text { Wisata }\end{array}$ & $\begin{array}{l}\text { Nomor } 453 \text { Tahun } \\
2018\end{array}$ \\
\hline 16. & $\begin{array}{l}\text { PT. Citra Wisata } \\
\text { Dunia }\end{array}$ & $\begin{array}{l}\text { Nomor } 665 \text { Tahun } \\
2017\end{array}$ \\
\hline 17. & $\begin{array}{l}\text { PT. Ceria Patria } \\
\text { Wisata }\end{array}$ & $\begin{array}{l}\text { Nomor } 314 \text { Tahun } \\
2018\end{array}$ \\
\hline 18. & $\begin{array}{l}\text { PT. Al Anshor } \\
\text { Madinah Barokah }\end{array}$ & $\begin{array}{l}\text { Nomor } 708 \text { Tahun } \\
2016\end{array}$ \\
\hline
\end{tabular}

Sumber: Kementerian Agama, 2020.

Berdasarkan pada data Sisko Patuh Kemeneterian Agama tercatat sebanyak 18 BPW di Yogyakarta telah memiliki ijin PPIU yang diberikan bagi BPW yang tidak memilik status daftar hitam dengan bentuk usahanya Perseroan Terbatas. Dari tabel diatas terlihat bahwa semua BPW yang telah mendapatkan SK PPIU dari kementerian Agama masih baru dengan waktu kurang dari 5 tahun. Hal ini mengambarkan bahwa mulai adanya kasadaran pihak BPW untuk melengkapi legalitas aspek dalam usahanya yang berupa ijin PPIU yang berlaku selama 3 tahun, dan akan dilakukan perpanjangkan ijin PPIU.
Salah satu syarat yang harus terpenuhi untuk perpanjangan ijin PPIU adalah sertifikasi usaha BPW.

\section{Tinjauan Kebijakan Penyelenggaraan Perjalanan Ibadah Umroh}

Berdasarkan Undang-Undang Republik Indonesia Nomor 8 tahun 2019 tentang Penyelenggaraah Ibadah Haji dan Umroh disebutkan dalam Bab 1 pasal 1 tentang ketentuan umum bahwa Penyelenggaraan Perjalanan Ibadah Umroh yang selanjutnya disingkat PPIU adalah Biro Perjalanan wisata yang memilik ijin dari Menteri untuk menyelenggaran ibadah perjalanan ibadah Umroh. Pada bab 7 pasal 89 tentang penyelenggaraan ibadah Umroh disebutkan bahwa untuk mendapatkan ijin PPIU, biro perjalanan wisata harus memenuhi persyaratan sebagai berikut : 1) pemilik dan pengelola merupakan warga negara Indonesia beragama Islam, 2) memilik Tanda daftar usaha pariwisata biro perjalanan yang sah, 3) mengelola usahanya dengan memperhatikan kemampuan finansial, manajerial, personalia, teknik, dan kompetensi, sebagai penyelenggara Ibadah Umroh yang dibuktikan dengan jaminan bank, 4) bekerjasama dengan biro penyelenggara ibadah Umroh di Arab Saudi yang mendapatkan izin resmi dan pemerintah kerajaan Arab Saudi, 5) Memiliki pengalaman memberangkatkan dan melayani perjalanan ke luar negeri sebagai biro perjalanan wisata yang berkualitas 6) berkomitmen untuk memberikan pelayanan dan meningkatkan kualitas penyelenggaraan Ibadah Umroh sesuai standar kementerian agama.

Undang-undang di atas menyebutkan dengan jelas bahwa Biro perjalanan yang melakukan usaha Penyelenggaraan Ibadah Haji dan Umroh diwajibkan memiliki sertifikat sebagai pelaku Usaha Biro Perjalanan Usaha, serta memiliki rekam jejak sebagai biro perjalanan wisata yang berkualitas dengan memiliki pengalaman memberangkatkan dan melayani perjalanan ke luar negeri. Sejak diberlakukannya peraturan ini oleh pemerintah, saat ini tidak sedikit BPW yang telah memilik ijin usaha PPIU bergerak dan mendaftarkan diri untuk mengikuti sertifikasi usaha BPW. Sertifikasi usaha BPW tidak hanya untuk memenuhi tuntutan dari pemerintah namun sertifikat sebagai BPW 
berlaku juga sebagai syarat untuk memperpanjang ijin PPIU.

Sedangkan menurut Keputusan Direktur Jenderal Penyelenggaraan Haji dan Umroh Nomor 337 tahun 2018 tentang Pedoman Akreditasi Penyelenggaraan Perjalanan Ibadah Umroh dengan prinsip jika PPIU harus mampu menunjukkan kemampuannya dalam pengelolaan administrasi dan manajemen dalam rangka tata kelola organisasi yang baik (good corporate governance), maka kriteria yang dinilai adalah administrasi manajemen dan kepatuhan dengan indikator capaian yaitu ketersediaan pedoman kerja yang jelas dan penerapan sistem manajemen yang berorentasi pada mutu pelayanan dan peningkatan berkelanjutan. Untuk memenuhi penilai ini maka PPIU setidaknya memenuhi 3 elemen ini, diantaranya adalah:

1. Memilik sertifikat ISO 9001 versi terbaru yang masih berlaku, sertifikasi biro perjalanan wisata yang masih berlaku

2. Memiliki sertifikat usaha sebagai biro jasa perjalanan wisata yang masih berlaku, dan pedoman kerja yang diterapkan

3. Memilik sertifikat usaha jasa yang masih berlaku

Meninjau dari Keputusan Direktur Jenderal Penyelenggaraan Haji dan Umroh Nomor 337 tahun 2018, setidaknya ada 3 elemen yang wajib di milik dan dipenuhi oleh BPW yang akan mengajukan ijin atau memperpanjang PPIU yaitu memilik sertifikat usaha jasa perjalanan wisata yang masih berlaku, dan pedoman kerja yang diterapkan. BPW tidak hanya wajib memilik sertifikat usaha biro perjalanan wisata namun juga diwajibkan untuk menerapkan standar yang telah ditetapkan oleh kementerian Pariwisata untuk bidang usaha Biro Perjalanan Wisata. Hal ini yang menjadi kendala bagi biro perjalanan wisata untuk menerapkan dan menjaga kualitas pelayanan agar sesuai dengan standar yang telah ditetapkan. Tidak sedikit Biro Perjalanan Wisata yang mengalami kesulitan dalam menerapkan standar usaha yang telah ditetapkan.

\section{METODE PENELITIAN}

Penelitian ini mengunakan metode penelitian kualitatif untuk mendapatkan data dan informasi yang dibutuhkan untuk melengkapi penelitian ini. Adapun teknik pengumpulan data yang digunakan dalam penelitian ini diantaranya adalah Wawancara Mendalam (Indepth Interview), Observasi, dan studi Kebijakan. Dalam melakukan wawancara, penentuan informan dari masyarakat dan instansi terkait diambil dengan mengunakan teknik snowball purposive sampling, yaitu peneliti menentukan sendiri orang tertentu yang dipertimbangkan akan memberikan data yang diperlukan.

Adapun penentuan informan dilakukan dengan mempertimbangkan batas berikut yaitu para pelaku usaha BPW Biro di Yogyakarta yang telah memilik sertifikat BPW dan memilik ijin PPIU dari Kementerian Agama Republik Indonesia dengan SK di atas 3 tahun serta telah melakukan usaha Biro Perjalanan Wisata untuk Ibadah Umroh dan Haji. Selain pelaku usaha biro perjalanan wisata dalam penelitian ini juga akan mengali secara dalam melalui wawancara dengan Lembaga sertifikasi usaha yang berada di Yogyakarta dan telah tersertifikasi oleh Komite Akreditasi Nasional (KAN) serta salah satu Auditor bidang Usaha perjalanan wisata, sehingga jumlah subjek informan dalam penelitian ini sebanyak 3 orang. Proses analisis data yang digunakan dalam penelitian ini berdasarkan pada pendapat Miles dan Huberman (1992:1920) yang menyatakan bahwa analisis terdiri dari tiga alur kegiatan yang terjadi secara bersamaan, yaitu reduksi data, penyajian data, dan penarikan kesimpulan/verivikasi.

\section{HASIL DAN PEMBAHASAN \\ Permenparekraf No.4 Tahun 2014 Tentang Standar Usaha Jasa Perjalanan Wisata}

Menurut Peraturan Menteri Pariwisata Dan Ekonomi Kreatif Republik Indonesia Nomor 4 Tahun 2014 Tentang Standar Usaha Jasa Perjalanan Wisata disebutkan bahwa Standar Usaha Jasa Perjalanan Wisata adalah rumusan kualifikasi Usaha Jasa Perjalanan Wisata dan/atau klasifikasi Usaha Jasa Perjalanan Wisata yang mencakup aspek produk, pelayanan dan pengelolaan Usaha Jasa Perjalanan Wisata. ${ }^{1}$ Peraturan menteri ini sudah disahkan dan dilaksanakan sejak tahun 2014 namun sayangnya pelaku usaha biro perjalanan wisata maupun agen perjalanan wisata belum memilik kesadaran untuk

1 Peraturan Menteri Pariwisata dan Ekonomi Kreatif Republik Indonesia Nomor 4 Tahun 2014 Tentang Standar Usaha Jasa Perjalanan Wisata 
melakukan sertifikasi usaha, begitu juga biro perjalanan wisata yang lebih fokus kepada pelayanan Haji dan Umroh. Namun sejak adanya moratorium Kementerian Agama yang mengatur dengan jelas bagi setiap Biro perjalanan wisata yang bergerak dalam usaha Umroh dan Haji wajib memilik sertifikat usaha BPW untuk membuat ijin PPIU ataupun memperpanjang ijin PPIU hal ini yang mneyebabkan tidak sedikitnya BPW Unroh Dan Haji melakukan sertifikasi. Hal ini dikarenakan jika BPW tidak memilik ijin PPIU maka diminta untuk menghentikan aktivitas pelayanan paket wisata Umroh.

Berdasarkan pada Peraturan Pemerintah Republik Indonesia N0. 52 Tahun 2012 Tentang Sertifikasi Kompetensi Dan Sertifikasi Usaha Di Bidang Pariwisata disebutkan bahwa Sertifikasi Usaha Pariwisata adalah proses pemberian sertifikat kepada usaha pariwisata untuk mendukung peningkatan mutu produk pariwisata, pelayanan, dan pengelolaan usaha pariwisata melalui audit. Sedangkan yang dimaksud dengan Standar Usaha Pariwisata adalah rumusan kualifikasi usaha pariwisata dan/atau klasifikasi usaha pariwisata yang mencakup aspek produk, pelayanan, dan pengelolaan usaha pariwisata. Sertifikat Usaha Pariwisata adalah bukti tertulis yang diberikan oleh lembaga sertifikasi usaha pariwisata kepada usaha pariwisata yang telah memenuhi standar usaha pariwisata.

Pada Pasal 3 dijelaskan bahwa Sertifikasi Usaha Pariwisata bertujuan untuk meningkatkan: a. kualitas pelayanan kepariwisataan; dan b. produktivitas usaha pariwisata. Di dalam bab III Pengembangan Sertifikasi Usaha Pariwisata pasal yang ke 17 disebutkan bahwa Setiap Pengusaha Pariwisata berkewajiban menerapkan Standar Usaha Pariwisata dalam menjalankan usaha pariwisata. Usaha pariwisata yang dimaksud meliputi bidang usaha: a) Daya tarik wisata; b) Kawasan pariwisata; c) Jasa transportasi wisata; d) Jasa perjalanan wisata; e) Jasa makanan dan minuman; f) Penyediaan akomodasi; g) Penyelenggaraan kegiatan hiburan dan rekreasi; h) Penyelenggaraan pertemuan, perjalanan insentif, konferensi, dan pameran; i) Jasa informasi pariwisata; j) Jasa konsultan pariwisata; k) Jasa pramuwisata; 1) Wisata tirta; dan m) Spa.

Peraturan Menteri Pariwisata Dan Ekonomi Kreatif Republik Indonesia Nomor
4 Tahun 2014 Tentang Standar Usaha Jasa Perjalanan Wisata, pada Bab II Pasal disebutkan bahwa Usaha Jasa Perjalanan Wisata meliputi : a. Biro Perjalanan Wisata, yang meliputi usaha penyediaan jasa perencanaan perjalanan serta usaha jasa pelayanan dan penyelenggaraan pariwisata termasuk perjalanan ibadah dan berbentuk badan usaha Indonesia berbadan hukum dan $b$. Agen Perjalanan Wisata (Permenparekraf, 2014:5). Pelaksanaan sertifikasi usaha perjalanan wajib dilakukan bagi pengusaha BPW, agar pelaku usaha dapat mengembangkan usaha baik dalam hal produk, pelayanan dan pengelolaan sehingga dapat memberi jaminan usaha serta jaminan kepastian bagi pelanggan.

Pada Pasal 9 tentang Penilaian dan Pelaksanaan Sertifikasi terdapat poin penting yang menjadi dasar agar mendapatkan sertifikat Usaha Jasa Perjalanan Wisata dengan melakukan penilaian untuk memenuhi persyaratan dasar yaitu ketersediaan Tanda Daftar Usaha Pariwisata Bidang Usaha Jasa Perjalanan Wisata.; dan pemenuhan dan pelaksanaan Standar Usaha Jasa Perjalanan Wisata. Jika BPW tidak memilik Tanda Daftar Usaha Pariwisata bidang BPW, maka sertifikasi tidak dapat dilakukan. Sedangkan Pemenuhan dan pelaksanaan Standar Usaha yang berlaku bagi Usaha Jasa Perjalanan Wisata, mencakup aspek :

Pertama, aspek produk meliputi 4 unsur dan terdiri dari 20 Sub unsur yang mengambarkan kaulitas produk yang di jual BPW. Pada aspek ini BPW tidak hanya dituntut memilik paket wisata saja namun juga detail informasi yang disampaikan pada paket wisata, namun juga mengatur tentang jaminan keselamatan berupa asuransi serta ketersediaan pemandu wisata yang kompeten dan profesional. Adapun unsur dan sub unsur pada aspek produk diantaranya sebagai berikut:

a. BPW memiliki layanan jasa pemesanan dan/atau penjualan paket wisata, layanan pemesanan akomodasi, pemesanan tiket perjalanan baik darat maupun udara, pemesanan transportasi, serta minimal menjual lebih dari 1 (satu) paket wisata yand dibuat sendiri.

b. Paket wisata yang dibuat dan dijual oleh BPW memuat keterangan tentang nama, durasi, rute dan kegiatan (tour itinerary), harga paket wisata disajikan dalam mata uang Rupiah, transportasi yang digunakan, 
akomodasi, asuransi perjalanan bagi wisatawan, serta menyediakan jasa pengurusan paspor dan visa.

c. BPW menggunakan jasa tenaga pemandu wisata mandiri yang memiliki sertifikat kompetensi yang masih berlaku, serta mampu berbahasa asing sesuai dengan bahasa yang digunakan oleh wisatawan mancanegara, atau sekurang-kurangnya mampu berbahasa Inggris. Disamping itu tenaga pemandu wisata tersebut haru dilindungi asuransi perjalanan wisata.

d. BPW menggunakan jasa tenaga pemandu wisata mandiri atau jasa pimpinan perjalanan wisata dilengkapi dengan Surat Tugas dan memiliki sertifikat kompetensi yang masih berlaku. Selain itu pimpinan perjalanan wisata tersebut mampu berbahasa asing sesuai dengan bahasa yang digunakan oleh wisatawan mancanegara, atau sekurang-kurangnya mampu berbahasa Inggris serta dilindungi asuransi perjalanan wisata.

Kedua, aspek pelayanan terdiri dari dari 2 unsur dan 7 Sub unsur yang lebih menitik beratkan pada standar pelayanan prosedur yang dilakukan oleh BPW. Unsur dan subunsur pada aspek pelayanan terdiri dari :

a. BPW diharapkan mampu menerapkan standar operating procedures (SOP) untuk melayani tamu yang meliputi layanan penyambutan kedatangan tamu, tata cara menerima dan melakukan panggilan telepon, prosedur menjelasan tentang produk yang disediakan/ditawarkan serta prosedur pemesanan dan/atau penjualan produk yang disediakan BPW.

b. BPW diharapkan mampu menerapkan Standar Operating Procedures (SOP) dalam pelaksanaan perjalanan wisata, yang meliputi penyediaan jasa tenaga pemandu wisata dan/atau pimpinan perjalanan wisata selama perjalanan wisata, handling complain terkait dengan pelayanan yang diberikan tenaga pemandu wisata dan/atau pimpinan perjalanan wisata selama perjalanan wisata, serta kesediaan wisatawan untuk mengisi kuesioner untuk evaluasi perjalanan wisata.

Ketiga, aspek pengelolaan yang terdiri dari 4 Unsur dan 11 Sub unsur. Pada aspek pengelolaan lebih banyak mengatur pada pengembangan dan pengelolaan usaha. unsur dan sub unsur pada aspek pengelolaan diantaranya adalah

a. BPW memiliki tempat usaha/kantor dengan mencantumkan alamat yang jelas, nomor telepon dan faksimili, serta alamat email yang masih berfungsi, serta kantor yang terpisah dari kegiatan keluarga/rumah tangga dengan, memiliki ruangan yang terdiri dari ruang kerja dan ruang penerimaan tamu dan dilengkapi dengan sarana, prasarana dan peralatan kantor yang memadai.

b. BPW memiliki tata kelola perusahaan dibuktikan dengan adanya struktur organisasi dan susunan pengurus, yang memuat nama, jabatan dan uraian tugas setiap bagian. Selain itu BPW diharapkan memilik tata cara pencatatan pemesanan dan/atau penjualan, serta surat-menyurat secara tertib dan baik minimal data yang tersimpan 3 tahun terakhir. yang terkait.

c. BPW mencatat seluruh transaksi pemesanan dan/atau penjualan secara tertib dan baik, minimal data yang disimpan 3 (tiga) tahun terdiri dari data pelanggan, data rekanan/ pemasok jasa., pengusaha daya tarik wisata, serta menyusun rencana pengembangan usaha.

d. BPW melakukan pengembangan sumber daya manusia dengan cara memiliki tenaga kerja tersertifikat kompetensi sesuai bidangnya dan melaksanakan program pengembangan SDM.

Standar usaha yang wajib dipenuhi oleh biro perjalanan wisata yang mengatur tentang standar produk, pelayanan dan pengelolaan biro perjalanan wisata. Tidak semua Biro Perjalanan Wisata mampu memenuhi standar yang telah ditetapkan oleh Kementerian Pariwisata dan Ekonomi Kreatif namun demikian pemerintah yang dibantu dengan lembaga sertifikasi usaha bidang pariwisata melakukan pembinaan dan pengawasan agar standar usaha ini dapat terpenuhi. Hal ini dapat dilakukan dengan cara BPW mendaftarkan diri untuk mengikuti sertifikasi usaha yang nantinya akan direspon oleh pihak Lembaga Sertifikasi Usaha dan dijadwalkan untuk pelaksanaan sertifikasi usaha.

Standar usaha biro perjalanan wisata disusun dan dibuat oleh kementerian pariwisata bukan untuk mengikat dan membatas pelaku usaha, namun melalui standar usaha ini diharapkan pelaku usaha 
dapat menigkatkan pelayanan serta kualitas produk, memilik legalitas aspek usaha disamping berfungsi juga untuk menjaga keamanan bagi pelaku usaha. Syarat dasar yang setidaknya harus terpenuhi untuk biro perjalanan wisata untuk menjalankan usahanya adalah Tanda Daftar Usaha Pariwisata (TDUP) yang wajib dimiliki oleh pelaku usaha yang telah mendapatkan Nomor Induk Berusaha (NIB) yang masih berlaku. Syarat dasar ini harus terpenuh sebelum biro perjalanan wisata mengajukan diri untuk mengikuti sertifikat usaha.

\section{Impelementasi Permenparekraf No.4 Tahun 2014 Tentang Standar Usaha Biro Perjalanan Pada Bpw Haji Dan Umroh Di Yogyakarta}

Peraturan menteri pariwisata dan ekonomi kreatif tentang standar usaha biro perjalanan wisata mulai disahkan sejak taun 2014 namun dalam pelaksanaanya belum banyak BPW yang mengetahui bahwa untuk melakukan usaha ada standar yang harus dipenuhi. Mengacu pada Peraturan Pemerintah Republik Indonesia No.52 tahun 2012 tentang sertifikasi kompetensi dan sertifikasi usaha dibidang pariwisata, ini yang menjadi dasar bagi Kementerian Pariwisata untuk mensosialisasikan dan menerapkan standar ini. Bagi biro perjalanan wisata yang telah memiliki pengalaman usaha cukup lama serta bergerak pada paket wisata Inbound, Ourbound, serta penjualan tiket pesawat maupun penyediaan voucher hotel ini bukan merupakan hal yang sulit untuk dipenuhi mengingat hal ini adalah pekerjaan sehari-hari yang dilakukan oleh pelaku usaha.

Kondisi ini jauh berbeda dengan Biro Perjalanan Wisata dengan pelayanan utamanya adalah paket Ibadah Umroh dan haji. Pada BPW Haji dan Umroh yang lebih fokus kepada Ibadah Umroh dan Haji sehingga produk wisata tidak dilaksanakan yang berakibat pada tidak terpenuhi standar usaha BPW. Implementasi Permenparekraf No.4 Tahun 2014 Tentang Standar Usaha Biro Perjalanan bagi BPW Haji dan Umroh sangat dibutuhkan karena untuk mendapatkan dan memperpanjang Penyelenggaraan Perjalanan Ibadah Umroh (PPIU) membutuhkan sertifikasi sebagai BPW. PPIU berlaku untuk 3 tahun, sehingga dengan peraturan baru ini menuntut BPW untuk melakukan sertifikasi
BPW sebelum mengajukan perpanjangan PPIU.

Berdasarkan hasil wawancara dengan Auditor Senior bidang Usaha Perjalanan Wisata (Edi Purnomo) Lembaga sertifikasi Usaha Bhakti Mandiri Wisata Indonesia Yogyakarta, ditemukan permasalahan utama yang dihadapi BPW Haji dan Umroh dalam menerapkan standar usaha dan upaya yang dapat dilakukan BPW Haji dan Umroh diataranya:

Pertama, BPW haji dan Umroh belum memiliki ijin usaha valid, terkini dan memadai. Seperti yang sudah disebutkan diatas syarat dasar dalam mengajikan sertifikasi BPW adalah memiliki legalitas aspek berupa Tanda Daftar Usaha Pariwisata (TDUP). Untuk mendapatkan TDUP ini, maka BPW mendaftarkan usahanya melalui pelayanan perijinan berusaha terintegrasi secara eletronik sektor pariwisata yang diawali dengan pengurusan Nomor Induk Berusaha (NIB) secara online. Persyaratan untuk mendapatkan Nomor Induk Berusaha adakah identitas pelaku usaha diterbitkan oleh Lembaga OSS setelah pelaku usaha melakukan pendaftaran. Adapun yang menjadi syarat dalam pendaftaran OSS diantaranya adalah nama pengusul dan nomor induk kependudukan; alamat; ruang lingkup usaha; serta syarat penanaman modal yang meliputi lokasi, besaran rencana, rencana tenaga kerja, nomor kontak usaha, fasilitas fiskal, kepabeanan, serta fasilitas lainnya dan NPWP Pelaku Usaha perseorangan.

Permohonan Perizinan Berusaha Sektor Pariwisata terdiri atas Izin Usaha, berupa TDUP diterbitkan oleh OSS berdasarkan komitmen serta Izin Komersial atau Operasional, berupa Sertifikat Usaha Pariwisata. Kondisi ini terjadi pada BPW haji dan Umroh yang memilik TDUP namun antara alamat usaha dengan yang dicantumkan pada TDUP berbeda, sehingga hal ini menjadi permasalahkan bagi BPW untuk mengikuti sertifikasi Usaha. selain itu ditemukan juga perbedaan alamat antara lokasi usaha dengan yang tertulis pada akta pendirian. Lokasi yang berbeda ini menjadi permasalahan yang sering dihadapi oleh BPW, hal ini disebabkan karena BPW belum memilik tempah usaha secara mandiri. Oleh sebab itu disarankan untuk pelaku usaha dapat menyesuaikan lokasi usaha seusai dengan yang tercantum dalam akta pendirian, jika BPW wisata belum memilik 
lokasi usaha sendiri dapat menunjukkan bukti perjanjian sewa tempat lokasi usaha, jika kontrak terdapat bukti kontrak minimal 2 tahun untuk BPW Non PPIU dan 4 tahun untuk PPIU.

Kedua, BPW Haji dan Umroh tidak memilik kerjasama dengan pihak luar. Kerjasama ini tidak hanya dengan BPW lain dalam penyelenggaraan Ibadah Haji dan Umroh namun juga kerjasama dengan pihak luar dalam hal ini adalah perwakilan yang ada di Arab Saudi untuk penyediaan Jasa angkutan wisata, pelayanan akomodasi, Perlindungan asuransi perjalanan wisata bagi jamaah, serta kerjasama dalam pengurusan visa. Kerjasama ini merupakan kesepakatan kedua belah pihak yang tertuang dalam Nota Kesepakatan dan memuat pasal-pasal yang mengatur pihak pertama dan pihak kedua, serta masih berlaku. Permasalahan ini sering ditemukan pada BPW yang akan melakukan sertifikasi usaha, oleh sebab itu disarankan bagi BPW Haji dan Umroh untuk dapat menyiapkan kontrak kerjasama sehingga pada saat sertifikasi usaha tidak menjadi temuan. Selain itu kerjasama ini yang tertuang dalam nota kesepakatan bersifat mengikat dan memberikan jaminan bagi pelaku usaha jika terjadi hal-hal yang tidak diinginkan seperti peserta meninggal, kecelakaan, sakit maupun keadaan force majeure seperti Wabah penyakit, bencana alam dan kerusuhan.

Ketiga, BPW haji dan Umroh dijalankan atas dasar percaya. Dalam menjalankan usahanya BPW tidak memilik kerjasama hal ini disebabkan usaha dilakukan atas dasar kepercayaan. Kepercayaan yang dibangun antara BPW Haji dan Umroh dengan vendor tanpa adanya perjanjian kerjasama yang sebenarnya befungsi untuk melindung pelaku usaha jika terjadi hal tak terduka seperti bencana alam, kematian, maupun wabah. Hal ini menjadi permasalahkan yang cukup besar karena tidak ada ikatan serta tidak sah secara hukum jika terjadi hal-hal mendesak BPW tidak dapat mengajukan klaim. Dasar kepercayaan ini juga dibangun antar pemilik saham dan pengelolan BPW dalam menjalankan usaha sehingga jika terjadi salah paham dan perbedaan visi dalam menjalankan usaha akan berdampak langsung pada hubungan kerjasama. Tidak jarang kondisi seperti ini terjadi dan berakibat pada pemutusan hubungan kerjasama. Oleh sebab itu perlu adanya kesepakatan perjanjian antara pemilik saham dan pengelola BPW, maupun kesepakatan perjanjian kerja antara pengelola BPW dengan tenaga kerja.

Keempat, status usaha BPW yang merupakan kerjasama antar teman dan anggota keluarga. Sebagian besar usaha BPW Haji dan Umroh didirikan oleh orang-orang yang mempunyai hubungan kekerabatan yang cukup dekat, maupun teman yang memilik persamaan visi. Usaha yang dilakukan bersama antara teman dan anggota keluarga tidak memilik pembagian tugas dan peran yang jelas dalam melakukan usaha, serta cenderung berada pada struktural manajemen. Disamping itu anggota keluarga maupun teman tidak memilik pengalaman dalam usaha BPW Haji dan Umroh sehingga tidak terlibat secara langsung dalam pengelolaan dan oprasional BPW.

Kelima, kurangnya pemahaman BPW tentang usaha perjalanan wisata karena fokus kepada aktivitas ibadah Umroh. Sejauh ini pelaku usaha BPW haji dan Umroh menitikberatkan pada penjualan paket ibadah Umroh dan haji sehingga tidak menjual paket wisata ziarah maupun wisata reguler dalam negeri. Disamping itu informasi yang didapatkan oleh pelaku usaha terkait standar BPW sangat terbatas, sehingga tidak banyak hal yang bisa disiapkan menjelaskan dilaksanakan sertifikasi usaha. Tidak sedikit pelaku usaha BPW haji dan Umroh yang mengetahui standar usaha BPW pada saat berlangsungnya sertifikasi tahap 1 , sehingga ditemukan banyak standar yang tidak terpenuhi sebagai usaha BPW.

\section{Kendala BPW dalam Menerapkan Standar Usaha Permenparekraf No.4 Tahun 2014}

Upaya pemenuhan standar usaha terus dilakukan oleh pelaku usaha guna meningkatkan pelayanan dan produk yang dijual. Tidak jarang pelaku usaha BPW Haji dan Umroh mengalami kesulitan dalam memenuhi standar usaha. Berdasarkan hasil wawancara dengan salah satu pelaku usaha BPW yang ada di Yogyakarta, terdapat beberapa kendala dalam memenuhi standar usaha BPW Haji dan Unroh dinataranya adalah :

1. Penyediaan jasa angkutan wisata.

Disebutkan dalam standar usaha BPW Haji dan Umroh bahwa Pelayanan transportasi Jemaah Umroh dilakukan oleh BPW yang telah memilik ijin PPIU 
meliputi pelayanan pemberangkatan ke dan dari Arab Saudi dan selama di Arab Saudi, transportasi Jemaah Umroh paling banyak 1 (satu) kali transit dengan menggunakan maskapai penerbangan yang sama dan memiliki izin mendarat di Indonesia dan Arab Saudi serta transportasi darat selama di Arab Saudi wajib memiliki tasreh/izin untuk pelayanan Umroh (PPIU, 2019). BPW harus menjamin ketersediaan transportasi wisata yang layak bagi calon jamaah mulai dari pemilihan penerbangan dari Indonesia sampai dengan transportasi lokal selama melaksanakan Ibadah Haji dan Umroh.

Sejauh ini tidak banyak BPW Haji dan Umroh yang memilik ijin IATA untuk dapat melakukan pemesanan langsung tiket penerbangan calon jamaat, namun BPW Haji dan Umroh melakukan pemesan penebangan melalui agen yang bekerjasama dengan maskapai penerbangan. Kondisi ini mengakibatkan pihak BPW Haji dan Umroh tidak memilik keluluasaan dalam memilih penerbangan serta jaminan kepastian penerbangan bagi calon jamaah karena dibatas oleh kuota penerbangan. Melalui Asosiasi Muslim Penyelenggara Haji dan Umroh Republik Indonesia (AMPHURI) BPW Haji dan Umroh saling bekerjasama dalam memberikan informasi terkait ketersediaan penerbangan Internasional untuk calon jamaah. Selain itu BPW Haji dan Umroh dapat mendaftarkan usahanya untuk menjadi Sub agen maskapai penerbangan dengan memenuhi syarat dan ketentukan yang ditetapkan oleh maskapai.

2. Perlindungan asuransi.

Bagi BPW Haji dan Umroh asuransi perjalanan bagi calon jamaah perlu untuk di siapkan, dalam hal ini asuransi berfungsi untuk mengcover resiko perjalanan bagi calon jamaah untuk paket Haji dan Umroh yang di jual (dapat menggunakan asuransi berjangka). Pelayanan perlindungan Jemaah Umroh dan petugas Umroh wajib dilakukan oleh BPW yang telah memilik ijin PPIU meliputi: a) asuransi jiwa, kesehatan, dan kecelakaan; b) pengurusan dokumen Jemaah yang hilang selama perjalanan ibadah; dan c) pengurusan Jemaah yang meninggal sebelum tiba kembali di tempat domisili (PPIU, 2019). Jaminan keselamatan melalui perlindungan asuransi tidak hanya berlaku untuk calon jamaah saja namun juga bagi pimpinan perjalanan ibadah Haji dan Umroh yang dapat dibuktikan dengan adanya dibuktikan dengan polis apabila sudah pernah melaksanakan paket wisata. Namun sayangnya tidak semua BPW memmberikan perlindungan asuransi karena tidak masuk dalam paket Haji dan Umroh.

3. Layanan pengurusan paspor dan visa.

BPW Haji dan Umroh dapat menyelenggarakan pengurusan langsung atau bekerjasama dengan BPW/pihak lainnya yang dapat dibuktikan dengan surat perjanjian kerjasama serta dokumentasi lain.dalam pengurusan maupun mengurus sendiri dengan menunjukkan bukti pengurusan. Kendala yang di hadapi BPW dalam memenuhi standar ini adalah:

a. BPW tidak memiliki kontrak kerja sama dengan perusahaan pelayanan Umroh dan telah mendapatkan pengesahan dari kementerian terkait.

b. BPW tidak memiliki kontrak kerja sama dengan perusahaan pelayanan Umroh di Arab Saudi dapat menjadi provider visa.

c. Dalam hal pengesahan yang dilakukan oleh Kementerian Agama, BPW yang telah memilik ijin PPIU wajib memenuhi persyaratan sebagai berikut: 1) memiliki izin operasional yang masih berlaku; 2) memiliki kontrak kerja sama yang telah ditandatangani oleh pimpinan perusahaan layanan Umroh di Arab Saudi dan PPIU yang telah disahkan oleh notaris; 3) memiliki sertifikat International Air Transport Association (IATA); 4) memiliki rekomendasi dari Asosiasi Penyelenggara Umroh; 5) memiliki kemampuan finansial yang dibuktikan dengan laporan keuangan yang telah di audit oleh akuntan publik; dan 6) memiliki komitmen mentaati peraturan perundang-undangan yang dibuktikan dengan surat pernyataan/pakta integritas (PPIU,2019)

4. Tenaga kerja tersertifikasi. 
Sesuai dengan standar yang ditetapkan bahwa BPW Haji dan Umorh diwajibkan mempekerjakan Tenaga pemandu wisata dan pimpimnan perjalanan wisata memiliki sertifikat kompetensi yang masih berlaku. Pemandu wisata dapat bersifat mandiri yang dibuktikan dengan list (yang memuat data detail) dan spesifikasi pemandu wisata serta bukti kerjasama antara BPW dan pemandu. Sedangkan untuk pemandu wisata yang merupakan karyawan BPW dibuktikan dengan kontrak kerja atau Surat keputusan, terdapat dalam struktur organisasi, terdapat Standar Oprasional Prosedur untuk pemandu wisata. Mengingat BPW Haji dan Umroh mengunakan jasa pembimbing ibadah Haji dan Umroh Ustad maupun Muthowif, sehingga standar ini tidak dapat dipenuhi. Oleh sebab itu BPW mengikutsertakan karyawan untuk mengukti sertifikasi kompetensi sesuai bidang yang diminta yaitu pramuwisata dan pimpinan perjalanan wisata.

5. Rencana pengembangan usaha.

BPW Haji dan Umroh yang telah aktif menjalankan usahanya, namun tidak memilik perencanaan pengembangan usaha dibuat secara menyeluruh dan komprehensif mengacu pada visi, misi yang mencakup baik dalam bentuk rencana jangka pendek, menengah, dan jangka panjang mencakup aspek produk, pelayanan, pengelolaan dan manajemen usaha. BPW Haji dan Umroh setidaknya menyusun isi rencana usaha meliputi pengembangan pengelolaan usaha, penambahan dan pembangunan ruang usaha, penerimaan dan penambahan karyawan, pengembangan produk, penambahan modal, informasi tentang jalannya usaha, posisi pasar, rincian profit, neraca perusahaan, proyeksi aliran kas untuk 2 tahun yang akan datang.

\section{SIMPULAN}

Berdasarkan hasil olah data dan analisis serta merujuk pada Peraturan menteri pariwisata dan ekonomi kreatif tentang standar usaha biro perjalanan wisata mulai disahkan sejak taun 2014 permasalahan yang di timbul dalam upaya melakukan standarisasi usaha BPW Haji dan Umroh sangat beragam. Permasalahan mendasar yang di hadapi oleh pelaku usaha BPW haji dan Umroh belum memiliki ijin usaha valid, terkini dan memadai yang merupakan syarat wajib yang harus terpenuhi sebelum mendaftarkan usaha untuk mengikuti proses sertifikasi. Tidak sedikit pula BPW Haji dan Umroh yang tidak memilik kerjasama dengan pihak luar khususnya dengan vendor seperti hotel, restoran, transportasi, pemandu wisata maupun dengan BPW lain, semua berdasarkan atas dasar percaya. Sering dijumpai usaha BPW yang merupakan kerjasama antar teman dan anggota keluarga sehingga tidak ada kejelaskan pembagian tugas pokok, dan pembagian hasil yang menjadi akar permasalahan dalam menjalankan usaha, serta kurangnya sosialisasi standar BPW kepada pelaku usaha BPW haji dan Umroh yang lebih fokus kepada aktivitas ibadah Umroh.

Berdasarkan pembahasan yang telah di uraikan terlihat bahwa BPW yang bergerak dalam bidang usaha Umroh dan Haji diwajibkan untuk memenuhi standar sebagai BPW, namun sayang masih banyak kendala dalam penerapan standar ini. Berdasarkan hasil wawancara dengan informan yang menjadi kendala dalam penerapan standar usaha BPW meliputi penyediaan jasa angkutan yang tidak memilik kerjasama dengan pihak ketiga, asurasi yang diberikan kepada calon jamaah maupun pimpinan perjalanan ibadah Haji dan Umroh. Kendala yang banyak dihadapi oleh BPW termasuk tentang pengurusan Visa, tidak mengunakan tenaga kerja yang tersertifikas untuk pemimpin perjalanan ibadah Umroh dan hari, serta pelaku usaha BPW Haji dan Umroh tidak menyusun rencana usaha yang dijabarkan dalam rencana jangka pendek, menengah, maupun panjang. 


\section{Kepustakaan}

Desky, M.A. 1999. Pengantar Bisnis Biro Perjalanan Wisata. Yogyakarta. Adicita Karya Nusa.

Desky, M.A. 1999. Manajemen Perjalanan Wisata. Yogyakarta. Adicita Karya Nusa.

Kesrul, M. 2003. Penyelenggaraan Oprasional Perjalanan Wisata. Jakarta. PT Gramedia.

Peraturan Pemerintah Republik Indonesia Nomor 52 Tahun 2012 Tentang Sertifikasi Kompetensi dan Sertifikasi Usaha di Bidang Pariwisata.

Peraturan Menteri Pariwisata dan Ekonomi Kreatif Nomor 1 Tahun 2014 Tentang Penyelenggaraan Sertifikasi Usaha Pariwisata.

Peraturan Menteri Pariwisata Dan Ekonomi Kreatif Republik Indonesia Nomor 4 Tahun 2014 Tentang Standar Usaha Jasa Perjalanan Wisata.

Peraturan Menteri Agama Republik Indonesia Nomor 8 Tahun 2018 Tentang Penyelenggaraan Perjalanan Ibadah Umroh.

Undang-Undang Republik Indonesia Nomor 8 tahun 2019 tentang Penyelenggaraan Ibadah Haji dan Umroh. 